\title{
Distribution and Determinant of Post-Operative Wound Infection among Patients underwent Routine Abdominal Surgery
}

\author{
Md. Mafiur Rahman ${ }^{1}$, SM Shafiul Azam Chaudhury ${ }^{2}$, Md. Atiqul Islam³, Mohammad Khurshidul \\ Alam $^{4}$, ABM Mir Mubinul Islam ${ }^{5}$, Abu Sayeed Mohammad ${ }^{6}$, Mohammad Ahtashamul Haque ${ }^{7}$ \\ ${ }^{1}$ Senior Consultant (Surgery), District Sadar Hospital, Joypurhat, Bangladesh; ${ }^{2}$ Senior Consultant (Surgery), General Hospital, \\ Cumilla, Bangladesh; ${ }^{3}$ Assistant Professor, Department of Surgery, Satkhira Medical College, Satkhira, Bangladesh; ${ }^{4}$ Associate \\ Professor, Department of Surgery, BGC Trust Medical College, Chittagong, Bangladesh; ${ }^{5}$ Senior Consultant (Surgery), District \\ Sadar Hospital, Joypurhat, Bangladesh; ${ }^{6}$ Associate Professor, Department of Skin \& VD, Mugda Medical College, Dhaka, \\ Bangladesh; ${ }^{7}$ Assistant professor, Department of Oral and Maxillo-Facial Surgery, Dhaka Medical College, Dhaka, Bangladesh
}

[Received: 7 March 2019; Accepted: 20 May 2019; Published: 1 June 2019]

\begin{abstract}
Background: Post-operative wound infection may occur after routine abdominal surgery. Objective: The purpose of the present study was to see the distribution and determinants of post-operative wound infection among the patients underwent routine abdominal surgery. Methodology: This non-randomized clinical trial was conducted in the different surgical units of the Department of Surgery at Sir Sallimullah Medical College \& Mitford Hospital, Dhaka, Bangladesh during January 2001 to December 2002 for a period of two (02) years. In the operation theatre, after anaesthesia skin was cleaned with Povidone iodine USP 5\% w/w or Spirit (70\% methylated spirit in water) or Chlorhexidine. During post-operative period dressing were left undisturbed unless it was felt necessary. Unusual pain in and around the wound was considered to be an indication of infection. A swab was taken from any discharge and was sent for bacteriological examination. Result: In this study, 50 patients were admitted as routine cases and undergone routine abdominal operations in general operation theatre. Out of 50 patients undergone routine abdominal surgery, 5 developed wound infection post operatively. Overall infection rate was $10.0 \%$. In routine abdominal operations, infection was $9.09 \%$ in upper midline or extended midline incision, $33.33 \%$ in lower midline, $6.25 \%$ right subcostal/Kocher's. In routine abdominal operations, the rate of infection in clean contaminated wound was $11.11 \%$, contaminated wound was $33.33 \%$. Wound infection rate was $20.0 \%$ cases in patients with malnutrition, $14.28 \%$ cases in obesity and $16.66 \%$ cases in diabetes mellitus. Conclusion: In conclusion post-operative wound infection is common in routine surgical operation. [Bangladesh Journal of Infectious Diseases, June 2019;6(1):16-21]
\end{abstract}

Keywords: Distribution and determinant; post-operative; wound infection; routine abdominal surgery

Correspondence: Dr. Md. Mafiur Rahman, Senior Consultant (Surgery), District Sadar Hospital, Joypurhat, Bangladesh; Email: drmafiurrahman@gmail.com; Cell no.: +8801728237077

Conflict of interest: There is no conflict of interest to any of the authors of this article.

Funding agency: The study was not funded by any authority.

Contribution to authors: Rahman MM, Chaudhury SMSA, Islam MA have contributed from protocol writing upto article write up. Alam MK, Islam ABMMM, Mohammad AS have revised and Haque MA has corrected the paper.

How to cite this article: Rahman MM, Chaudhury SMSA, Islam MA, Alam MK, Islam ABMMM, Mohammad AS, Haque MA. Distribution and Determinant of Post-Operative Wound Infection among Patients underwent Routine Abdominal Surgery. Bangladesh J Infect Dis 2019;6(1):16-21

Copyright: @2019. Rahman et al. Published by Bangladesh Journal of Infectious Diseases. This article is published under the Creative Commons CC BY-NC License (https://creativecommons.org/licenses/by-nc/4.0/). This license permits use, distribution and reproduction in any medium, provided the original work is properly cited, and is not used for commercial purposes. 


\section{Introduction}

Infection is the invasion of the body by the pathogenic micro-organisms with consequent local and systemic effect ${ }^{1}$. For this, a sufficient number of pathogens must enter the tissues, overcome the patients resistance and multiply. The development of infection in incisional wounds continues to be one of the most serious complication that can occur in surgical patients ${ }^{2}$. Surgical practice primarily aims at healing of the wounds without serious complications. Considerably confusion persists about the incidence, source, causes and nature of surgical infection that occur in post-operative wounds. However, the incidence of wound infection following abdominal operations, especially in emergency cases is still regrettably high. Wound infection causes prolongation of convalescence, prolonged hospital staying, economic loss, unpleasant dressing, necrosis of the skin edges, septicaemia, ugly scar and production of dangerous focus of infection in the surgical wards ${ }^{3-5}$.

Unnecessary trauma from retractors, inappropriate use of electro coagulation of bleeding points, foreign bodies and dead space contribute heavily to postoperative wound infection ${ }^{6}$. Whenever gross contamination of the wound cannot be avoided, the skin and subcutaneous tissue should be left open. Since even a minor post-operative wound infection prolongs hospitalization and occasion's economic $\operatorname{loss}^{7}$. Every effort must be made to keep the infection rate low.

Usually post-operative wound infection appear between $3^{\text {rd }}$ to $5^{\text {th }}$ post-operative days. Unusual wound pain and post-operative fever may alarm the wound infection and. immediate wound inspection and palpation is indicated ${ }^{8}$. If the wound is infected, then immediate appropriate management needs to be initiated. Therefore this present study was undertaken to see the distribution and determinants of post-operative wound infection among the patients underwent routine abdominal surgery.

\section{Methodology}

This non-randomized clinical trial was conducted in the different surgical units of the Department of Surgery at Sir Sallimullah Medical College \& Mitford Hospital, Dhaka, Bangladesh during January 2001 to December 2002 for a period of two (02) years. In this study, patients had been selected irrespective of age and sex. Patients were admitted as routine cases and undergone routine abdominal operations in General operation theatre. Every patient was evaluated clinically by junior surgeons under strict supervision of the unit head for the whole period of hospital stay. For routine cases all routine and diagnostic investigations as far as possible were done. Particular attention was paid to diabetic status; drugs used especially steroids and any immunosuppressive drugs and presence of concurrent disease. Patients were examined carefully with particular attention to the vital parameters, general physical built, nutritional status, anaemia, jaundice and any septic focus. Patients were given necessary treatment where indicated. For skin preparation, the day before the operation patients took bath using toilet soap in routine cases. In the operation theatre, after anaesthesia skin was cleaned with Povidone iodine USP 5\% w/w or Spirit $(70 \%$ methylated spirit in water) or Chlorhexidine. During operation all incisions were made in such a way so that it gave a good view of the deeper part of the operation field. Injury to the important structures were carefully avoided. Incision length was made adequate to give good exposure. Superficial and deep fascial layers were incised in the same way. Proper haemostasis was done with diathermy coagulation. Sometimes catgut was used to ligate the bleeding vessels. Every effort was made to protect the wound margin from contamination. Standard technique was adopted to close different types of incisions. All types of suture materials were used during closure. Peritonium was closed either with chromic catgut or as a part of mass closure with Prolene, Dexon or Vicryl. Muscular layers were usually apposed by chromic catgut. In fatty abdomen subcutaneous fat was apposed with plain catgut. Interrupted silk stitches were used to close the skin. A drain tube or saline set was used whenever it was indicated. The tubes were brought out through a separate stab wound. Drain tubes were attached to evacuated saline bag. At the end of the operation, wound was cleaned with dilute savlon and spirit soaked sterile swab. In some cases, sterile gauze pieces were used to cover the wound, which were kept in positions with the help of micropore. In others, wound was covered with sterile surgical dressing.

Postoperative period: During post-operative period dressing were left undisturbed unless it was felt necessary. Unusual pain in and around the wound was considered to be an indication of infection. As soon as the dressing was found to have socked, the wound was examined. A swab was taken from any discharge and was sent for bacteriological examination. Any persistent fever after that period was carefully and thoroughly investigated. The drainage tube was removed after cessation of discharge from $2^{\text {nd }}$ to $5^{\text {th }}$ post-operative 
days according to the nature of operation. Wound exposed and explored by removing few sutures for established/suspected infection-subsequently dressed regularly sometimes using EUSOL soaked gauze, wherever required for chemical desloughing.

\section{Result}

In this study, 50 patients were admitted as routine cases and undergone routine abdominal operations in General operation theatre. Out of 50 patients undergone routine abdominal surgery, 5 developed wound infection post operatively. Overall infection rate was $10.0 \%$. Post-operative wound infection was occurred in cholecystectomy in chronic cholecystitis, partial gastrectomy in carcinoma of stomach, nephrolithotomy or pylolithotomy in renal stone or stone in the renal pelvis, transvesical or retropubic prostatectomy in benign enlargement of prostate (BEP), abdomino-perineal resection (APR) in carcinoma rectum operation (Table 1).

Table 1: Rate of Wound Infection in Routine Abdominal Surgery

\begin{tabular}{|l|l|c|c|}
\hline Name of the diseases & Name of the Operations & $\begin{array}{c}\text { Number of } \\
\text { operation }\end{array}$ & $\begin{array}{l}\text { Number of } \\
\text { Infection( \%) }\end{array}$ \\
\hline Chronic cholecystitis & Cholecystectomy & 11 & $1(9.09)$ \\
\hline $\begin{array}{l}\text { Chronic cholecystitis } \\
\text { With choledocholithiasis }\end{array}$ & $\begin{array}{l}\text { Cholecystectomy With } \\
\text { choledocholithotomy }\end{array}$ & 8 & $0(0.0)$ \\
\hline Ca. stomach & Partial gastrectomy & 6 & $1(16.66)$ \\
\hline GOO due to pyloric stenosis & $\begin{array}{l}\text { Bilateral trunkal vagotomy \& gastro- } \\
\text { jejunostomy }\end{array}$ & 2 & $0(0.0)$ \\
\hline Inguinal hernia & Herniotomy \& herniorrhaphy & 6 & $0(0.0)$ \\
\hline Burger's disease & Bi-lateral lumber sympathectomy & 2 & $0(0.0)$ \\
\hline $\begin{array}{l}\text { Renal stone/Stone in } \\
\text { the renal pelvis }\end{array}$ & Nephrolithotomy/pylolithotomy & 4 & $1(25.0)$ \\
\hline $\begin{array}{l}\text { Benign enlargement of } \\
\text { prostate(BEP) }\end{array}$ & $\begin{array}{l}\text { Transvesical/retropubic } \\
\text { prostatectomy }\end{array}$ & 2 & $1(50.0)$ \\
\hline Vesical calculi & Suprapubic cystolithotomy & 1 & $0(0.0)$ \\
\hline Incisional hernia & Mesh/anatomical repair & 3 & $0(0.0)$ \\
\hline $\begin{array}{l}\text { Chronic intestinal } \\
\text { (large) obstruction }\end{array}$ & Right hemicolectomy & 1 & $0(0.0)$ \\
\hline Carcinoma rectum & Abdomino-perineal resection (APR) & 2 & $1(50.0)$ \\
\hline Pancreatic calculi & $\begin{array}{l}\text { Removal of stone with pancreatico- } \\
\text { jejunostomy (Roux-en-Y) }\end{array}$ & 1 & $0(0.0)$ \\
\hline Recurrent appendicitis & Interval appendicectomy & 1 & $0(0.0)$ \\
\hline Total & & $\mathbf{5 0}$ & $\mathbf{5 ( 1 0 . 0 )}$ \\
\hline
\end{tabular}

In routine abdominal operations, infection was $9.09 \%$ in upper midline or extended midline incision, $33.33 \%$ in lower midline, $6.25 \%$ right subcostal/Kocher's, $16.66 \%$ in lumber, $33.33 \%$ in Pfannentiei incision and no infection in inguinal, upper right paramedian, Lanz and rooftop incisions (Table 2).

Infection rate varies with the duration of operations. Up to 1 hour, it was $4.16 \%$ and for more than 1 hour, it was $15.38 \%$ in routine cases (Table 3 ). In this series in routine abdominal operations, the rate of infection in clean contaminated wound was $11.11 \%$, contaminated wound was $33.33 \%$ and no infection in clean wound (Table 4).
Table 2: Incision and Infection in Routine Abdominal Surgery

\begin{tabular}{|l|c|c|}
\hline Site of Incisions & $\begin{array}{l}\text { No. of } \\
\text { Incisions }\end{array}$ & $\begin{array}{l}\text { No. of } \\
\text { Infection }\end{array}$ \\
\hline $\begin{array}{l}\text { Upper midline or } \\
\text { extended midline }\end{array}$ & 11 & $1(9.09 \%)$ \\
\hline Lower midline & 3 & $1(33.33 \%)$ \\
\hline Rt. sub-costal/kocher's & 16 & $1(6.25 \%)$ \\
\hline Upper right paramedian & 3 & $0(0.0 \%)$ \\
\hline Inguinal & 6 & $0(0.0 \%)$ \\
\hline Lumber & 6 & $1(16.66 \%)$ \\
\hline Pfannenstiel & 3 & $1(33.33 \%)$ \\
\hline Lanz & 1 & $0(0.0 \%)$ \\
\hline Rooftop & 1 & $0(0.0 \%)$ \\
\hline
\end{tabular}


Table 3: Duration of Operation and Wound Infection Rate

\begin{tabular}{|l|c|c|}
\hline $\begin{array}{l}\text { Duration of } \\
\text { Operation }\end{array}$ & $\begin{array}{l}\text { Total No. of } \\
\text { Operations }\end{array}$ & $\begin{array}{l}\text { Number of } \\
\text { Infection }\end{array}$ \\
\hline 0 to $1 \mathrm{hr}$. & 24 & $1(4.16 \%)$ \\
\hline$>1 \mathrm{hrs}$. & 26 & $4(15.38 \%)$ \\
\hline
\end{tabular}

Wound infection rate also varies with the conditions of the host. During routine abdominal surgical operation wound infection rate was $20.0 \%$ cases in patients with malnutrition, $14.28 \%$ cases in obesity, $16.66 \%$ cases in diabetes mellitus, $20.0 \%$ cases in CPOD, $22.22 \%$ cases in malignancy. Some patients had more than one coexistent diseases/conditions (Table 6).

Table 5: Rate of Infection in Various Types of Wounds

\begin{tabular}{|l|c|c|}
\hline Type of wounds & Total & $\begin{array}{l}\text { Number of } \\
\text { Infection }\end{array}$ \\
\hline Clean & 11 & $0(0.0 \%)$ \\
\hline Clean contaminated & 36 & $4(11.1 \%)$ \\
\hline Contaminated. & 03 & $1(33.3 \%)$ \\
\hline Dirty & 00 & $0(0.0 \%)$ \\
\hline
\end{tabular}

\section{Discussion}

Post-operative wound infection is still a major problem of surgical practice 4 . In spite of tremendous advances in surgical techniques, sterilization method, operation theatre designs and invention of newer and newer antibiotics in recent years, wound infections continues to play a role in post-operative morbidity ${ }^{9}$. Different workers in this field have given their own thoughts and ideas for the control of infection.

Table 6: Host Condition and Wound Infection Rate

\begin{tabular}{|l|c|c|}
\hline Host conditions & Total & $\begin{array}{c}\text { Number of } \\
\text { Infection }\end{array}$ \\
\hline Malnutrition & 15 & $3(20.0 \%)$ \\
\hline Obesity & 7 & $1(14.28 \%)$ \\
\hline Diabetes mellitus & 6 & $1(16.66 \%)$ \\
\hline Jaundice & 8 & $0(0.0 \%)$ \\
\hline COPD & 5 & $1(20.0 \%)$ \\
\hline Malignancy & 9 & $2(22.22 \%)$ \\
\hline
\end{tabular}

In this series, 50 cases were included. They were selected randomly (double blind technique). They were admitted in different surgical units of Sir Salimullah Medical College \& Mitford Hospital,
Dhaka during the period from January, 2001 to December 2002. Out of them, 50 patients were admitted as routine cases and undergone routine abdominal operations in general operation theatre (GOT). Out of 50 cases of routine abdominal surgery, 5 developed post-operative wound infection. The overall infection rate is $10.0 \%$ for routine abdominal surgery.

All patients were shaved and cleaned before operation by the nursing staffs. In the operation on a hair bearing area, hair is usually shaved, however, rough shaving produces abrasion. Simple bathing with soap and water or detergent is all that is usually carried out ${ }^{10}$. Any form of abrasion during shaving must be avoided as it may cause colonization of bacteria which results in higher wound infection rate. The abdomen swabbed from the proposed line of incision to the periphery. Swabbing cannot eradicate the whole bacterial population ${ }^{11}$. The transient bacteria which are on the surface are killed by skin antiseptics but cannot destroy the deep resident bacteria. In this series, most of the patients were washed by povidone iodine. Thus, post-operative wound infection was not significantly higher. Povidone iodine is a safe and effective means of reducing wound sepsis following gastro-intestinal surgery ${ }^{12}$.

In this series, infection rate is lower in routine abdominal operations (10\%). Most of the routine operations were performed by senior experienced surgeons (Professor/assistant professor). The infection rate is higher where the operations were done Junior-less experienced surgeons in comparison to operation performed by seniorexperienced Surgeons ${ }^{13}$. The probable causes of disparity are the less experienced surgeons do nothandle tissues gently. Gentle and meticulous techniques with absence of haematoma formation in the operative area achieved low infection rate ${ }^{14}$. Inadequate and improper haemostasis instead of catching a bleeding point with the tip of the haemostate or a dissecting forceps the learners catches the bleeding point along with the surrounding tissues and then bum. This result in large amount of dead tissues. It is preferable to coagulate the vessels alone without a mass of surrounding tissue so as to ensure correct haemostasis and avoid unnecessary tissue damage ${ }^{12}$.

In this series, the rate of wound infection in different incisions in routine abdominal surgery were recorded. In routine abdominal procedures the infection rate was higher in upper midline with extended midline incision $(33.33 \%)$ and in Pfannenstiel incision (33.33\%) and no infection in 
inguinal, upper right paramedian, Lanz and Rooftop incisions. The causes of variation of infection rate in different type of incision may be due to Infection rate was higher when operations were done with a big incision like extended midline. Exposer time was more and more chance of tissue handling caused infection ${ }^{12}$. Another cause is type of operation. In contaminated and dirty operation, infection rate is high whatever incision was used ${ }^{10}$.

There is a relation between the length of operating time and infection rate. In this series the rate of wound infection was about 3 to 4 times more when the duration was about 2 to 3 time more. Other studies $^{7-9}$ also shown a rise in infection rate associated with prolongation of the operation time. The possible explanations are dosage of bacterial contamination increases with the time. Wounded tissues are damaged by drying and by exposure to air and retraction. Increased amount of suture and electrocoagulation may reduce the local resistance of the wound. Longer procedures are more liable to be associated with blood loss and shock, thereby reducing the general resistance of the patients ${ }^{12}$.

Wound infection rate varies according, to the type of operation. Infection rate is known to be higher in emergency surgery as compared to elective procedure. Because most of the laparotomy for emergency cases are associated with peritonitis, intestinal strangulation, gross abdominal contamination and adverse host factors ${ }^{4}$. In this series, in routine cases the wound infection rate was $10.0 \%$ (5 out of 50 cases). The wound infection rate in clean contaminated cases was $11.11 \%$ (4 out of 36 cases); contaminated wound was $33.33 \%$ ( 1 out of 3 cases) and no infection in clean wound. This study showed that when the wounds were clean peroperatively, infection rate was low. However, when there was per-operative contamination, the rate of infection were higher as compared with the following studies. In a 10 years prospective study of 62,939 wounds the wound infection rate in clean wounds was found in $1.5 \%, 7.7 \%$ in clean contaminated wounds, $15.2 \%$ cases in contaminated wounds and $40 \%$ cases in dirty wounds ${ }^{17}$. In another study ${ }^{13}$ the wound infection rate in clean wound is $25 \%$, clean contaminated wounds in $28.6 \%$ cases and contaminated wounds $54.8 \%$ cases.

Wound infection rate also varies with the conditions of the host ${ }^{9}$. In this series, in malnutrition wound infection rate was $20.0 \%$ in routine cases; in obesity $14.28 \%$; in diabetes mellitus $16.66 \%$; in COPD $20 \%$; in malignancy $22.22 \%$ cases. Wound infection is a major source of morbidity in surgical patients. It results prolonged hospital stay, unwanted time and monetary loss and sometimes operative failure ${ }^{8}$. The main determinants of infection are micro-organisms, the environment and host defense mechanisms. There is a continuous interaction between these three factors. Postoperative wound infection though higher in emergency surgery, but it is not clear that whether the infection is due to higher per operative wound contamination or not. Other factors for postoperative wound infection includes malnutrition, obesity, COPD, diabetes mellitus, obstructive jaundice, malignancy, steroids or other immunosuppressive drugs, duration of surgery and age and sex of the patients ${ }^{14}$.

\section{Conclusion}

In conclusion, rate of infection after routine surgical operation is varied with different types of incisions as well as different sites of operation. The rate of infection is also significantly high in routine surgical operation. In this study it has been found that the rate of wound infection in routine surgical operation is more in long duration of operative cases. The rate of infection is very high in contaminated wound. During routine abdominal surgical operation wound infection rate is comparatively high in malnutrition, in obesity, in diabetes mellitus, in CPOD and in malignancy.

\section{References}

1. Azoury SC, Farrow NE, Hu QL, Soares KC, Hicks CW, Azar F, Eckhauser F. Postoperative abdominal wound infection-epidemiology, risk factors, identification, and management. Clinical wound care management and research. $2015 ; 2: 137-48$

2. Horan TC, Gaynes RP, Martone WJ, Jarvis WR, Emori TG. CDC definitions of nosocomial surgical site infections, 1992: a modification of CDC definitions of surgical wound infections. Infection Control \& Hospital Epidemiology. 1992;13(10):6068.

3. Malone DL, Genuit T, Tracy JK, Gannon C, Napolitano LM. Surgical site infections: reanalysis of risk factors. Journal of Surgical Research. 2002;103(1):89-95.

4. Owens CD, Stoessel K. Surgical site infections: epidemiology, microbiology and prevention. Journal of Hospital Infection. 2008;70:3-10.

5. Coello R, Charlett A, Wilson J, Ward V, Pearson A, Borriello P. Adverse impact of surgical site infections in English hospitals. Journal of Hospital Infection. 2005;60(2):93103.

6. Anderson DJ, Kaye KS, Classen D, Arias KM, Podgorny $\mathrm{K}$, Burstin $\mathrm{H}$, et al. Strategies to prevent surgical site infections in acute care hospitals. Infection Control \& Hospital Epidemiology. 2008;29(S1):S51-61.

7. Leong G, Wilson J, Charlett A. Duration of operation as a risk factor for surgical site infection: comparison of English and US data. Journal of Hospital Infection. 2006;63(3):255-62. 8. Tanner J, Norrie P, Melen K. Preoperative hair removal to reduce surgical site infection. Cochrane database of systematic 
reviews. 2011(11).

9. Bowler PG, Duerden BI, Armstrong DG. Wound microbiology and associated approaches to wound management. Clinical microbiology reviews. 2001;14(2):24469.

10. Hemingway P, Allcock N, Payne H, Tanner J. Preoperative hair removal to reduce surgical site infection. Best Practice, 2007;11 (4), pp.1-4

11. Bratzler DW, Houck PM, Workgroup SI. Antimicrobial prophylaxis for surgery: an advisory statement from the National Surgical Infection Prevention Project. The American Journal of Surgery. 2005;189(4):395-404
12. McKibben L, Horan TC, Tokars JI, Fowler G, Cardo DM, Pearson ML, Brennan PJ. Guidance on public reporting of healthcare-associated infections: recommendations of the Healthcare Infection Control Practices Advisory Committee. Infection Control \& Hospital Epidemiology. 2005;26(6):580-7. 13. Berríos-Torres SI, Umscheid CA, Bratzler DW, Leas B, Stone EC, Kelz RR, et al. Centers for Disease Control and Prevention guideline for the prevention of surgical site infection, 2017. JAMA surgery. 2017;152(8):784-91

14. Nichols RL. Preventing surgical site infections: a surgeon's perspective. Emerging infectious diseases. 2001;7(2):220. 